\title{
CHARACTERISTICS AND DYNAMICS OF THE SAND DUNE VEGETATION AT NORTH BAY, TASMANIA
}

\author{
by J. B. Kirkpatrick, T. Leaman, A. Pennington and T. Pollard
}

(with four tables, five text-figures and nine plates)

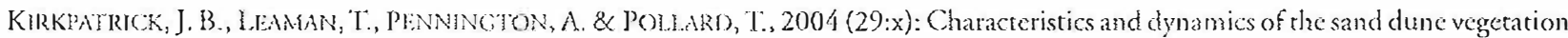
at North Bay, Tasmania. Papers and Proceedings c!(the $\mathrm{R}_{0}$ al Sociely of Tasmania ! 38: 37-45.

https://doi.org/10.26749/rstpp.138.37 ISSN 0080-4703. School of Geography and Environmental Studies, University oflasmania, Privare Bag 78, Hobart, 'fasmania 7001, Australia ()BK, TL, AP, Tl'). 'Author for correspondence.

The vegetation of the coastal sand dunes at North Bay on the Foresticr Peninsula was surveyed in 80 quadrats along seven transects. A total of six plant communities was identified; four from the back dunes and rwo from the fore dunes. The back dunes were dominated by Banksia marginata Cav and the fore duncs by Spinifex sericeus R. Brand Acacin sophorae (Labill.) R. Br. Size class analysis of age classcs of the back dune vegeration indicated an eventual senescence of the dominant $B$. marginata and a replacement by closed canopy trees from wet eucalypt forest, such as Notelaca ligustrina Vent. Tivo communities were found to be of high conscrvarion significance: a S. sericezs grasstand from the fore dunc and a closed-forest communiry from the back dunes. Both communities are in a relatively undisturbed state, although the $S$. sericeus grassland has been invaded by exoric herbs. For these significant communities to remain incact, wecds and human acrivicy must be controlled on the fore dunes and fire excluded from the back duncs.

Key Words: Banksia, sand dune vegetation, conservation, management, succession, Tasnania.

\section{INTRODUCTION}

The coastal sand dune vegetation of Tasmania has close affinities with the coastal sand dunc vegetation of the humid tcmperate parts of southeastern Australia (Kirkpatrick 1993, Clarke 1994). This vegetation has been relatively well-cescribed, both for the State as a whole (Harris 1991, Kirkpatrick 1993, Kirkparrick \& Harris 1995, 1999), and for particular areas (Bowden \& Kirkpatrick 1974, Chladil \& Kirkpatrick 1989, Harris \& Kirkpatrick 1996). However, the two detailed studies of succession in Tasmanian coastal sand dune vegetation (Bowden \& Kirkpatrick 197'́, Chladil \& Kirkpatrick 1989) relate to dune systems that have been subject co a high degree of disturbance from either clearance and stock grazing, or thcinvasion of marram grass (Ammophila arenaria (L.) Link).

North Bay ( $\left.42^{\circ} 52^{\prime} S 147^{\circ} 56^{\circ} \mathrm{E}\right)$, located on the northern end of the Forestier Peninsula, soucheast Tasmania, has one of the few coastal sand dune systems in eastem Tasmania that has not been strongly disturbed by people and has not been invaded by marram grass. Blowouts have been substantial between the 1940s and the present (pls 1,2), possibly caused by rising sea levels (Komar et at. 1991, Healy 1996, Nicholls \& Leatherman 1996). The patterns of fires on acrial photographs indicate that two lagoons, Swan Lagoon and Top Lagoon, and their outct to the sea, have provided a barrice to the movement of fire from adjacent dry eucalypt forest into the dine system (fig. 1, pl, 1). Only two parts of the coastal dune system have been burned since 1946. one berween 1966 and 1975 , probably in 1967, and one between 1975 and 1986, possibly in 1983. The 1946 phocograph clearly shows the effects of fuc on a morc substantial part of the dune (pl. 1). This may have occutred in the fire $y$ ear of 1939. Within the area that was not burnt in these fres, there is evidence of an older fire which burned all but a small pare of the dune system on which trees of species with aerial parts that are normally killed by fire are substantial cnough in size to suggest a century without its incidence. This fire possibly occurred in the fire year of 1898 . These four distince fire ages (putatively' 1898, 1939, 1967, 1983) provided us with an opportunity to infer the nature and dynamics of long-term succession in castern Tasmanian back dune systems. We also describe the zonation patterns on the relatively undiscurbed fore dunes and discuss the conservacion management needs of the system.

\section{METHODS}

$\Lambda$ total of $805 \times 5 \mathrm{~m}$ quadrats were surveyed along seven cransects, located orthogonally to the line of the dunes (fig. 1). Quadrats were located contiguously in each transect. All species of vascular plant within each quadrat were recorded, using the following cover scale: $1=<1 \%, 2=1-5 \%$,

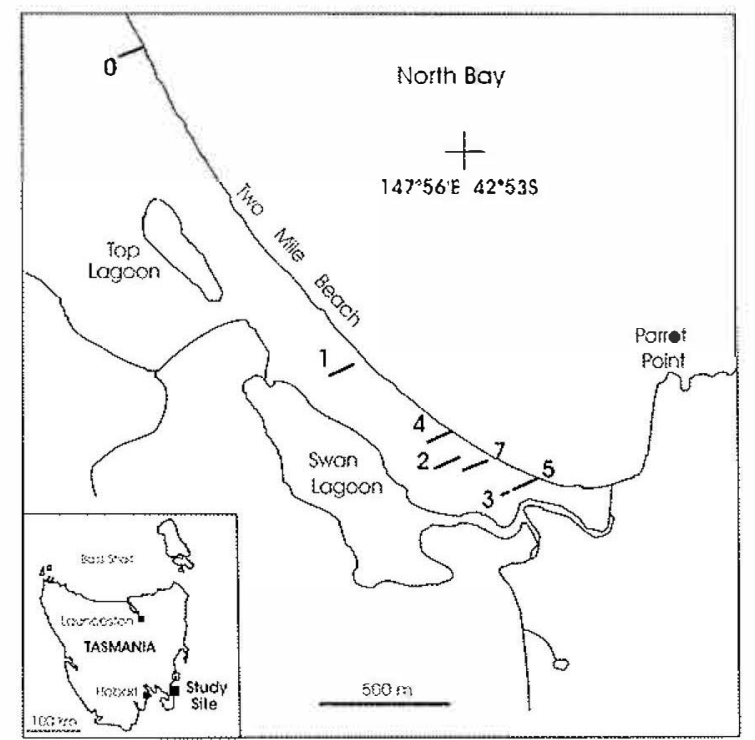

$F G$. I - Lation of Nonth Bay shouning the position of the seven transects along the dune system. Tiansect 6 is the fore dane portion of tiansect 0 . 


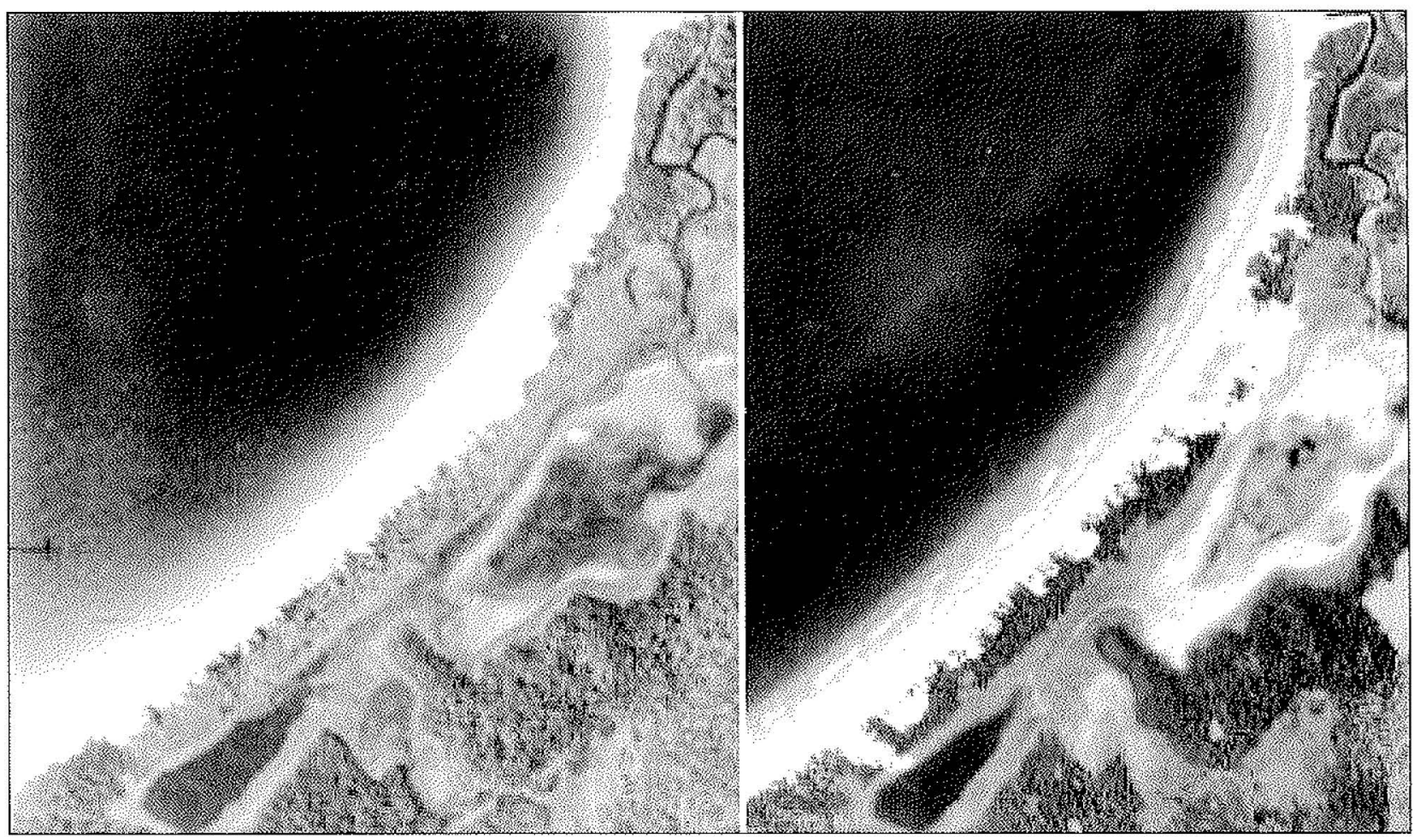

PLATE I

The dune system in 1946 (lefl) and 2000 (right). The eastem end of the beach is at the top of the photographs. Note the unburned section between the beach and the dune outlet in 1946, and the tmansgression of sand between the two dates.

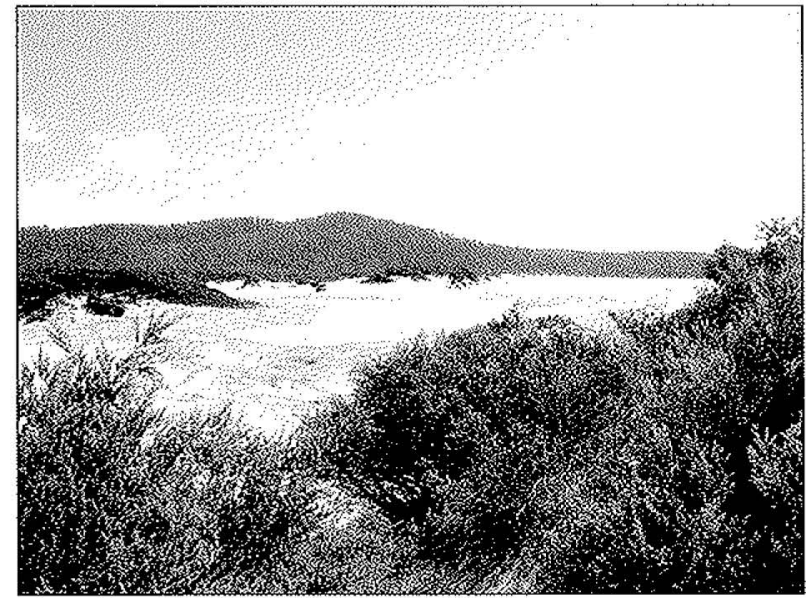

PLATE 2

The major blowout on North Bay Beach. Note Leptospermum lanigerum in foreground.

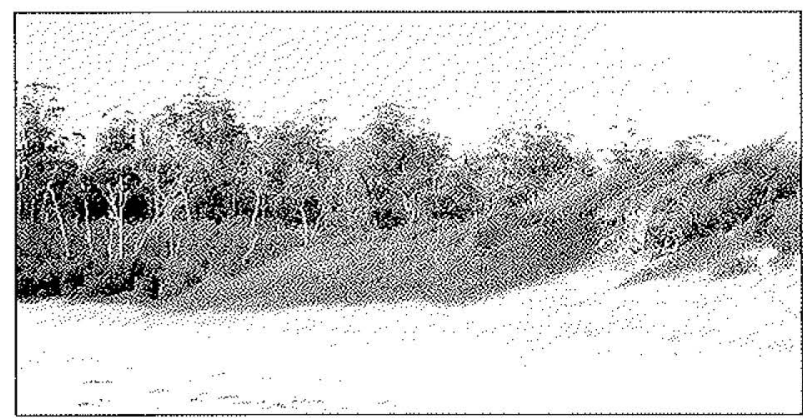

$$
\text { PLATE } 4
$$

Spinifex hirsutus grassland with Acacia sophorac beath on the seaward slope of the fore dune at the eastern end of the beach. The live eucalypts in the background are not on the sand dune system.

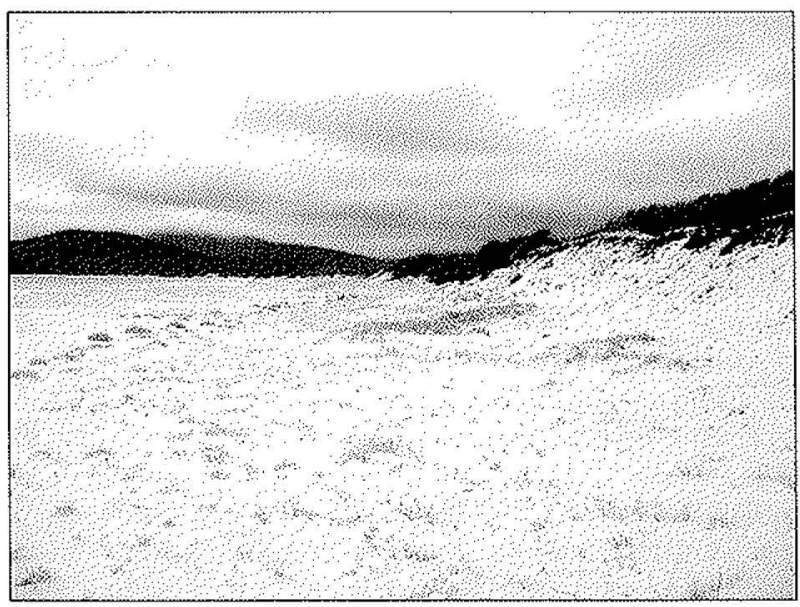

PLATE 3

Spinifex sericeus grassland on the beach berm. Cakile spp. occur to the seauard of $S$. sericeus. Note the receding foredune.

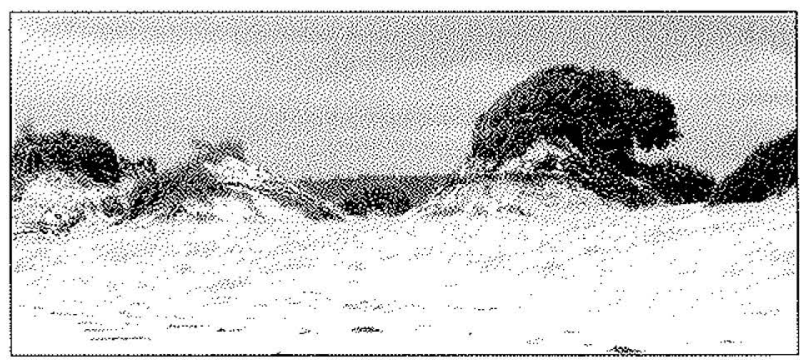

PLATE 5

Exposed Banksia marginata roots provide evidence of retreat of the line of the forcdune. Note the fossil soil horizon exposed by the retreat. Spinifex sericeus grasland in the foreground. 
$3=5-25 \%, 4=25-50 \%, 5=50-75 \%, 6=75-100 \% . A$ species was considered to be present if any of its aerial organs were found overhangirg the quadrat. Species nomenclature follows Buchanan (1999).

Within ench quadrat the location and circumference at breast height $(1.3 \mathrm{~m})$ of each stem of all trees were recorded and the basal area calculated. Where a tree had more than one stem, the area of each stem at breast height was calculated. These figutes were added to give the basal area for the individual. The height and number of branch whorls of all seedlings of Banksia marginata Cav were also noted. I"lhe slope of the quadrat was measured using a clinometer and the soil noted as grey or yellow sand.

The quadrats were ordinated, using the default options for global non-metric multidimensional scaling in DECODA (Minchin 1994). The cover codes were used as input. The scores for dimensions 1 to 4 were used as the input to a classification of quadrats which used Ward's agglonerative method with Euclidcan distance in Minitab 13 for Windows. One-way ANOVA was used to test for significant differentiation between ages of back dune forest in the ordination scores and species richness.

\section{RESULTS AND DISCUSSION}

\section{Beach Berm and Fore Dune Vegetation}

Two of the six communities selected from the dendrogram were located on the seaward side of the fore dunes. These were 4 and 6 (tables 1, 2). Community 4 was a Spinifox sericeus R.Bi. - (Austrofestuca litoralis (Labill.) E. Alcxeev) tussock grassland ( $p l .3)$, in which $S$. scriceus was the dominant species, constituting $13.93 \%$ of the plant cover and occurring in all the quadrats (tables 1,2). Other common taxa in the community werc Cakilespp., with a cover of $1.1 \%$ occurring in $30 \%$ of surveyed quadrats, Correa alba Andrews $10.5 \%$ cover in $20 \%$ of the quadrats), Pteridium esculentum (Forst. f.) Cockayne and Isolepis nodosa (Rottb.) R.Br. (both with $0.2 \%$ cover and in $20 \%$ of the quadrats).

Acacia sophone (Labill.) R.Br. shrubland occured where the scaward slope of the foredune was stable $(p \mid, 4)$. A. sophorne was present in all quadrats in group 6 and constituted more than half the plane cover (tables 1,2 ). $S$. sericeus and Carpobrom rossii (Haw.) Schwantes were the next most frequent species occurring in $40 \%$ of the quadrats, with $13.1 \%$ and $0.4 \%$ cover respectively (cables 1,2 ). A herb that is absenc from secure reserves in Tasmania, Calystegia soldanella (L.) R.Br., also occuls in the community.

While typical sequences of species on the seaward side of the dunes are shown in figures 2 and 3 , it must be noted that the prevailing condition of the dunes was retrear (pls 1, 2), with root systems of $B$, magmata being exposed in many places (pl. 5). The exposure of a palacosol has given the opportunity for soll-stored seed of a heath plant, Aotus ericoides (Vent.) G.Don, to germinate and establish (pl. 6). This species was not observed on any part of the back dune, and may indicate more frequent fire than at present in the eiglateenth or bineteenth centuries, as it is usually a component of heath or hearhy understories to eucalypt woodland/forest.

The presence of the original native sand-binders (e.g., $S$. sericeus and $A$. littoralis), and the relatively low abundance of introduced species, is a distince feature of the fore dune vegetation at North Bay. Many Tasmanian beaches, especially those of the north and east coasts, have been invaded by the exotic species $A$. arenaria and Euphorbia paralias L., which have displaced many of the native sand-binding species (Kirkpatrick \& Harris 1999). The fore dune vegetation at Noth Bay has high conscrvation significance, as it is one of the last beaches on the 'Tasmanian cast coast where the native sand-binders still retain dominance. However, individuals of $E$. paralias have been uprooted by the owners of most of the dunes, and were observed and removed in the course of our data collection.

\section{Succession on the Back Dunes}

Four age classes were evident in the back dune vegetation at North Bay. The 1983 age class $(0$, table 3$)$ still had charcoal on dead large individuals of $B$. marginata, and had numerous $B$. marginata seedlings and shrubs, with whorl counts that varicd from 1 to 42 (fig. 4).

The quadrats in this age class all belonged to community one (table 4). P. esculentum is the species with the most cover in this community. The relatively open conditions favoured a high species richness, consisting mostly of herbs and grasses (tables 1, 2, 3).

The vegetation of the area of the back dunes that was probably burned in botb 1939 and 1967 (1, table 3) was a tangled $B$. marginata closed-scrub incerspersed with small patches of $P$. esculentum fernland. The quadrats fell in communicics 2,3 and 5 (table 4), indicating that variation in the vegetation of the back dunes as a whole was not responding only to time since fire. Leucopogon lanceolatus, Leptospermum scoparium and L. lanigerum wore relatively abundant as small trees at this site (table 3). There was a very small basal area of dead stems compared with the older sites, and quadrat species richness was the Jowest of all four age classes (table 3). The numerous individuals of $B$. marginam generally have relatively small basal areas (fig. 5), and there are no seedlings.

'The quadrats in the area probably last burned in 1939 (age class 2, table 3) stupported a B. marginata open forest with a scattered layer of smali trees of Monotoca glanca (Labill.) Druce, in turn overlaying a dense bracken understorey. There was a large proportion of dead stems of $B$. marginata, and a small area near the wetland where Acacia melanoxylon R.Br. occurred. The quadrats mostly fell into group 3 , but there were some in groups 1 and 2 (table 4). There is a wide range of basal area classes of $B$. marginata in the stand, but few fall in the smaller classes (fig. 5), and there are no seedlings.

A late stage in succession in the back dune vegetation is evident in the area possibly last burned in the fire year of 1898 (age class 3, table 3), where many B. matginata individuals are dead or dying (pl. 7). The mean basal area of dead stems of $B$. marginata is approximately two-thirds of the mean basal area of live stems (table 3). Large and healthy individuals of Notelact ligusina Vent., Pittosporum bicolor Hook., Olearia argophylla (Labill.) Benth. and Coprosma quadrifida (Labill.) Robinson (table 3) appear to be in the process of forming a closed-canopy forest (p). 7). However, no seedlings of any tree species were found in the quadrats. Dense and tall bracken occurs everywhere except directly under the densest parts of the tree canopies (pl. 8). This dense cover may inhibit tree establislament. There is some evidence that the above species have established adjacent 
TABLE 1

Mean percentage cover of species by communities defined by floristic composition

\begin{tabular}{|c|c|c|c|c|c|c|}
\hline \multirow[b]{2}{*}{ Species } & \multicolumn{6}{|c|}{ Conxmunity } \\
\hline & 1 & 2 & 3 & 4 & 5 & 6 \\
\hline Ainiplex cinerea & - & - & - & 0.05 & $\sim$ & - \\
\hline Austrofestucn lintoralis & - & - & - & 0.1 & - & - \\
\hline Cakile spp.* & - & - & - & 1.1 & - & - \\
\hline Calystegia soldanella & - & - & - & 0.05 & - & -- \\
\hline Eupborbia paralias* & - & - & - & 0.05 & - & - \\
\hline Spinifex sericous & - & 0.2 & $\ldots$ & 13.925 & - & 13.1 \\
\hline Conea alba & - & 0.2 & - & 0.5 & - & - \\
\hline Rhagodia candolleana & 5 & - & - & 0.05 & - & - \\
\hline Acacia sophome & - & 1.267 & - & - & - & 56.1 \\
\hline Carpobrotus rossii & - & 0.333 & - & - &.- & 0.4 \\
\hline Isolepis spp. & - & 0.2 & 0.071 & 0.2 & - & - \\
\hline Pelargonium australe & - & 0.067 & 0.071 & 0.15 & - & - \\
\hline Actites megalocarpa & $\cdots$ & 0.2 & 0.071 & 0.15 & 0.063 & 0.2 \\
\hline Pteridium esculentum & 38.727 & 17.2 & 9.357 & 0.2 & 29.656 & 0.2 \\
\hline Leucopogon parviforus & 1.909 & 5.167 & 1.357 & 0.05 & -.. & - \\
\hline Austrodanthonia setacea & 4.909 & - & 0.071 & - & - & 0.2 \\
\hline Acacia melanoxylon & - & 2.5 & - & - & - & - \\
\hline Carcx appressa & - & 0.067 & - & - & - & - \\
\hline Deyeuxia spp. & - & 0.067 & - & - & - & - \\
\hline Dichelachne crinita & - & 0.133 & - & - & $\ldots$ & - \\
\hline Olacia phlogopappa & - & 0.2 & - & - & - & - \\
\hline Picris spp.* & - & 0.067 & - & - & $\ldots$ & - \\
\hline Acetosella vulgaris* & 0.273 & 0.067 & - & - & - & - \\
\hline Leptinella reptans & 0.091 & 0.067 & - & - & - & - \\
\hline Scnecio minimus & 0.727 & 0.133 & - & - & - & - \\
\hline Wablenbergia spp. & 1.909 & 0.067 & - & - & - & - \\
\hline Leontodon taraxacoides & - & 0.067 & 0.071 & $\cdots$ & - & $\cdots$ \\
\hline Lobelia alata & $\ldots$ & 0.133 & 0.143 & - & - & - \\
\hline Solanum laciniatum & - & 0.067 & 0.214 & - & - & - \\
\hline Dianella tasmanica & 0.636 & 0.067 & - & - & 0.063 & - \\
\hline Leptospermum scoparitu & - & 1.4 & 0.357 & - & 0.125 & - \\
\hline Senecio spp. & - & 0.133 & 0.357 & - & 0.375 & $\ldots$ \\
\hline Agrostis billardierei & 0.182 & 0.4 & 0.714 & - & 0.25 & - \\
\hline Banksia marginata & 10.5 & 13.567 & 51.893 & - & 12.938 & - \\
\hline Dichondra repens & 1.091 & 0.2 & 0.357 & - & 0.063 & - \\
\hline Lomandra longifolia & 8 & 0.067 & 0.429 & - & 4.344 & - \\
\hline Olearia lirata & 10.318 & 0.133 & 5.571 & - & 2.469 & - \\
\hline Oxalis perennans & 2.182 & 0.067 & 0.143 & - & 0.063 & - \\
\hline Coprosma quadrifida & - & - & $\cdots$ & - & 11.406 & - \\
\hline Goodenia lanata & - & - & - & - & 0.063 & - \\
\hline Laginifera stipitata & - & - & - & - & 0.063 & - \\
\hline Notelaen ligustrina & $\ldots$ & - & - & - & 15.938 & - \\
\hline Olearia argophylla & - & - & - & - & 7.188 & - \\
\hline Pittosporum bicolor & - & - & - & - & 16.75 & $\ldots$ \\
\hline Sellieva radicans & - & - & - & - & 0.063 & - \\
\hline Acacin verticillata & 1.636 & . & - & - & 0.188 & - \\
\hline Hydrocotyle hirta & $\ldots$ & - & 0.357 & - & 0.688 & - \\
\hline Letucopogon lanceolatus & - & - & 7.143 & - & 1.125 & - \\
\hline Monotoca glanea & - & - & 10.857 & $\ldots$ & 2.125 & - \\
\hline Polystichum proliforum & - & - & 0.357 & - & 4.594 & - \\
\hline Viola bederacea & - & - & 0.071 & - & 0.125 & -. \\
\hline Ehrharta stipoides & 0.818 & - & 0.071 & - & 0.063 & - \\
\hline Acaena novac-zelandiace & 0.091 & - & - & - & - & - \\
\hline Airasp.* & 3.455 & - & - & - & - & - \\
\hline Astroloma humifusum & 0.818 & - & - & - & - & - \\
\hline
\end{tabular}

* exotic taxon. 
TABLE 2

Percentage frequency of species by communities defined by floristic composition

\begin{tabular}{|c|c|c|c|c|c|c|}
\hline \multirow[b]{2}{*}{ Species } & \multicolumn{6}{|c|}{ Community } \\
\hline & 1 & 2 & 3 & 4 & 5 & 6 \\
\hline Atriplex cinerea & - & - & - & 5 & - & - \\
\hline Austrofestuca littoralis & - & - & - & 10 & - & - \\
\hline Cakile spp. * & - & - & - & 30 & - & - \\
\hline Calystegia soldanella & - & - & - & 5 & - & - \\
\hline Eupharbia paralias* & - & - & - & 5 & - & - \\
\hline Spinifex sericeus & - & 6.67 & - & 100 & - & 40 \\
\hline Covea alba & - & 6.67 & - & 20 & - & - \\
\hline Rhagodia candolliana & 63.64 & - & - & 5 & - & - \\
\hline Acacia sophorae & - & 20 & - & - & - & 100 \\
\hline Carpobrotus rossii & - & 20 & - & - & $\cdots$ & 40 \\
\hline Isolepis spp. & - & 20 & 7.14 & 20 & - & - \\
\hline Pelargonitm australe & - & 6.67 & 7.14 & 15 & - & - \\
\hline Actites megalocurpa & - & 6.67 & 7.14 & 15 & 6.25 & 20 \\
\hline Pteridium esculentum & 100 & 100 & 42.86 & 20 & 100 & 20 \\
\hline Leucopogon parviflorus & 45.45 & 60 & 21.43 & 5 & - & $\cdots$ \\
\hline Austrodanthonia setacea & 72.73 & - & 7.14 & - & - & 20 \\
\hline Acacia melanoxylon & - & 6.67 & - & - & - & - \\
\hline Carex appressa & - & 6.67 & - & - & - & -- \\
\hline Deyeuxia spp. & - & 6.67 & - & - & - & - \\
\hline Dichelachne crinita & $\ldots$ & 13.33 & - & - & - & $\ldots$ \\
\hline Olearia phlogopappa & - & 6.67 & - & - & - & - \\
\hline Picris spp. * & - & 6.67 & - & - & - & - \\
\hline Acctosella tulgaris* & 9.09 & 6.67 & - & - & - & - \\
\hline Leptinella reptans & 9.09 & 6.67 & - & - & - & - \\
\hline Senecio minimus & 36.36 & 13.33 & - & - & - & $\ldots$ \\
\hline Wablenbergia spp. & 45.45 & 6.67 & - & $m$ & - & - \\
\hline Leontodon taraxacoides* & - & 6.67 & 7.14 & - & - & - \\
\hline Lobelia alaia & - & 13.33 & 14.29 & - & - & - \\
\hline Solanum laciniatum & - & 6.67 & 7.14 & - & - & - \\
\hline Dianella tasmanica & 27.27 & 6.67 & - & - & 6.25 & - \\
\hline Leprospermum scoparitum & - & 20 & 21.43 & - & 12.5 & - \\
\hline Senecio spp. & - & 13.33 & 21.43 & - & 37.5 & - \\
\hline Agrostis billardierei & 18.18 & 13.33 & 28.57 & - & 25 & - \\
\hline Banksia marginata & 100 & 86.67 & 100 & - & 93.75 & - \\
\hline Dichondra repens & 72.73 & 20 & 21.43 & - & 6.25 & - \\
\hline Lamandra longifolia & 90.91 & 6.67 & 28.57 & - & 56.25 & - \\
\hline Olearia liratn & 63.64 & 13.33 & 21.43 & - & 18.75 & - \\
\hline Oxalis perennans & 54.55 & 6.67 & 14.29 & $-m$ & 6.25 & - \\
\hline Coprosma quadrifida & - & - & - & - & 75 & - \\
\hline Goodenia lanata & - & - & - & - & 6.25 & - \\
\hline Laginifent stipitata & - & - & - & - & 6.25 & - \\
\hline Notclaea ligustrina & - & $\cdots$ & - & - & 37.5 &.- \\
\hline Olearia argophylla & - & - & - & - & 18.75 & - \\
\hline Pittosporum bicolor & - & - & - & - & 37.5 & - \\
\hline Sellicra radicans & - & - & - & - & 6.25 & - \\
\hline Acacin verficillata & 18.18 & - & - & - & 6.25 & - \\
\hline Hydrocotyle hirn & - & - & 35.71 & - & 56.25 & - \\
\hline Lencopogon lanccolatus & - & - & 14.29 & - & 12.5 & - \\
\hline Monotoca glauca & - & - & 50 & - & 25 & - \\
\hline Polystichum proliferum & - & - & 21.43 & - & 31.25 & - \\
\hline Viola bedenacea & - & - & 7.14 & - & 12.5 & - \\
\hline Ehrbarta stipoides & 45.45 & - & 7.14 & - & 6.25 & - \\
\hline Acaena novac-zelandiae & 9.09 & - & - & - & - & - \\
\hline Airasp.* & 72.73 & - & - & - & - & - \\
\hline Astroloma bumifusum & 45.45 & - & - & - & - & - \\
\hline
\end{tabular}

* Exotic taxon. 


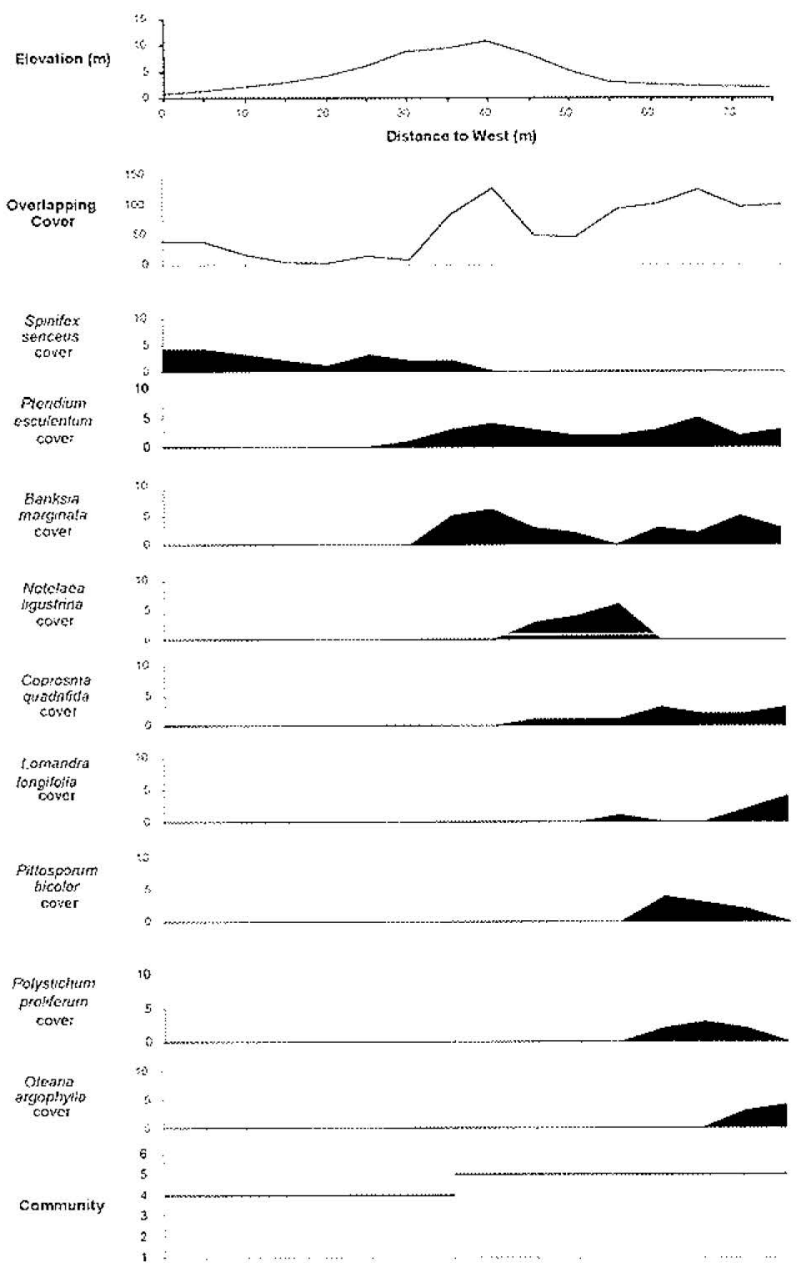

FIG. 2 - Topography, overlapping cover and species coner code value for plant species at transecis 3 and 5 .

to the trunks of individuals of $B$. marginata (pl. 8). This may rclate to a high likelihood of bird-dispersed species being found under perching trees, or to the relative lack of shoot comperition where the B. marginata roots inhibit bracken growth.

Between the $B$. marginatr scrub and forest and the wetland herbfields to the rear, there is a zone of low closed forest dominated by $A$. melenoxylon and a zone of closed scrub dominated by Leptospermum lanigerum (Aiton) Smith. The large blowout dune shown in plate 2 has partly buried both these zones and large areas of $B$. marginata forest. Only $L$. lanigerum has been able to survive this burial, protruding anomalously from the top of the tallest dune in the system (pl. 2).

At the castern end of the back dunes there are several large dead eucalypts (p). 9). The canopies of these encalypts are visible in the 1946 photograph. As the area has not been burned since 1946, we assume that the eucalypts died of old age.

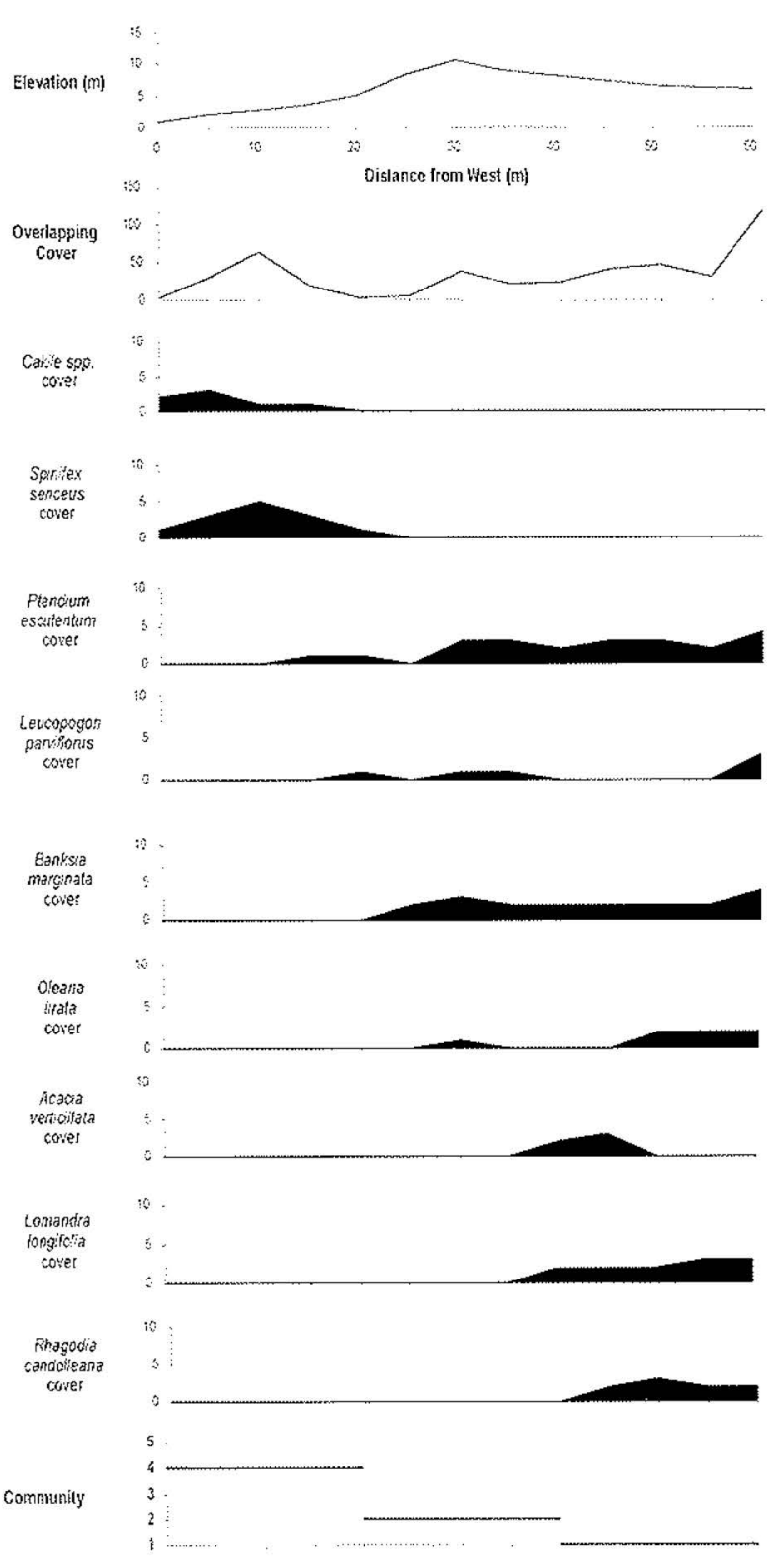

FIG. 3 - Topography overlapping cover and species cover code value for plant species at transed 6 .

\section{CONSERVATION AND MANAGEMENT}

The S. sericow grassland has the higher conservation significance of the rwo communities on the fore dunes ar North Bay. Despite being well-reserved in Tasmania (Kirkpatrick \& Harris 1995), it does not occupy a large area, due to its displacement by exotic species such as $A$. arenaria and $E$. paraliasand destruction by off-road vehicles. The unseserved herb $C$. soldanella also occurs in the fore dune vegetation. The S. sericeus grassland at North Bay is of high conservation significance not only in terms of the vegetation it contains, but also for the local beach-nesting birds such as the Hooded Plover (Thinomis rubricolls Machews, 1912). The Hooded Plover uses the open vegetation above the high ride mark for nesting sites. On beaches where introduced species, especially A. aronaria, have established, the vegetation is mansformed from an open grassland to a closed, much more dense one 


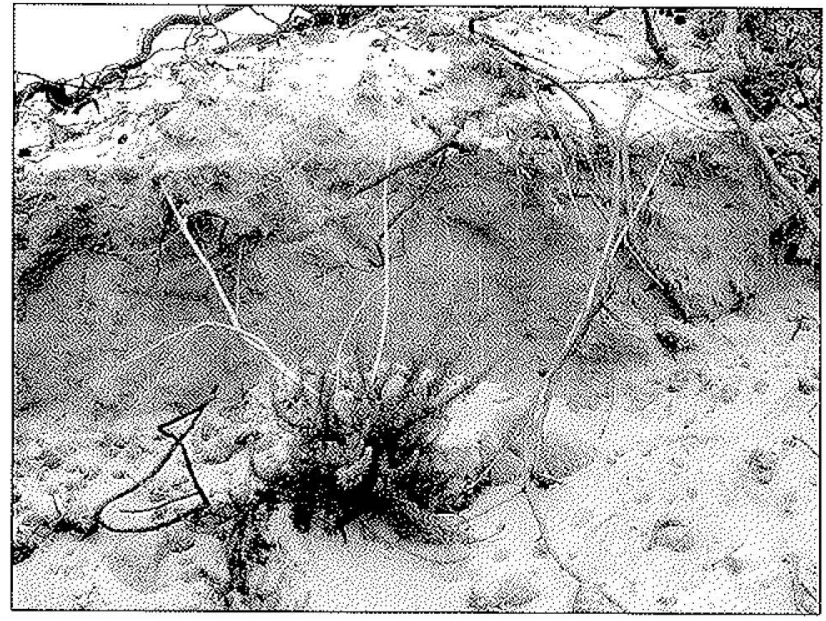

PLATE 6

Aotus ericoides, still attached to the exposed fossil soil horizon within the truncated fore dune.

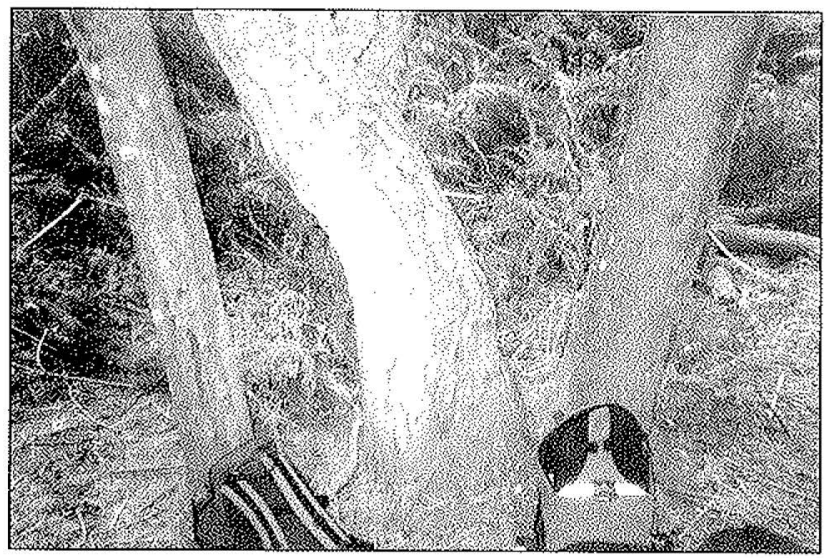

PLATE \&

Two Pittosporum bicolor trmks on either side of a dead Banksia marginata.

where the Hooded Plover, and other beach-nesting birds, are prevented from establishing their nests. These birds prefer the open vegetation where they nest among natural debris and, occasionally, in C. rossii. Thus it is imperative that the integrity of the fore dune vegetation be maintained, through the prevention of weed establishment and the continued exclusion of off-road vehicles. Both $A$. arenaria and $E$. paralias are spread by ocean currents and collectively are the most scrious theats to coastal biodiversity in Tasmania. Landowners and users of the beach ar North Bay need to be vigilant to prevent the establishment of these exoric species. Monitoring of the fore dune vegetation must be constant in order to recognise the arrival of exotic species and remove them before they can become established.

The vegetation of the long-unburned part of the back dune system is not replicated in eastern Tasmania, although a form of pent-forming rainforest is known from longunburned coastal dunes in sout ${ }_{1}$ west Tasmania (Jarman $e t$ al. 1991). Thus, although we have some indication in the vegetation (pls 6,9) that the dune system may have been burned more frequently in she past, continued exclusion of fire scems the best management option to maintain overall diversity in Tasmania's constal vegetation, while obviously potentially leading to the local depletion of some disturbance-requiring coastal specics.

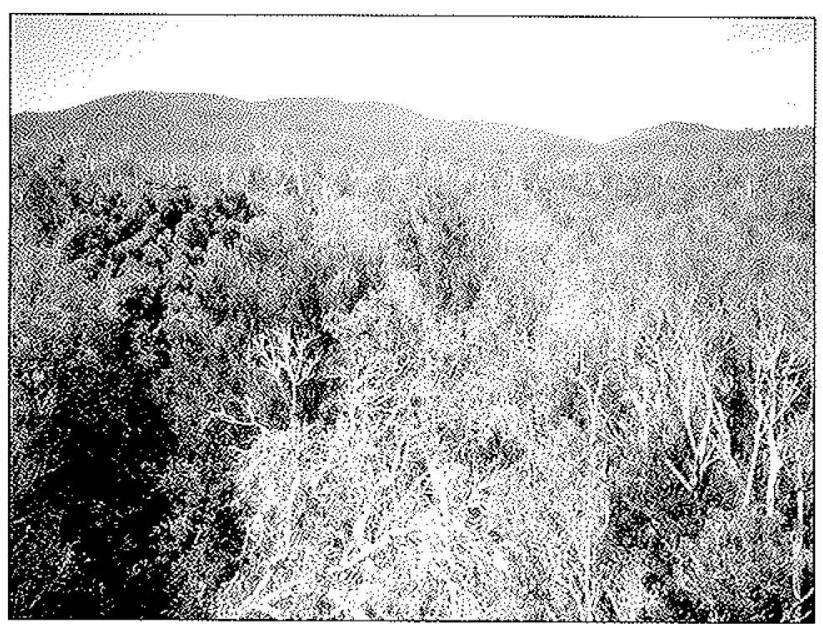

PLATE 7

Closed canopy trees, including Notelaca ligustrina and Pittosporum bicolor among senescing Banksia marginata.

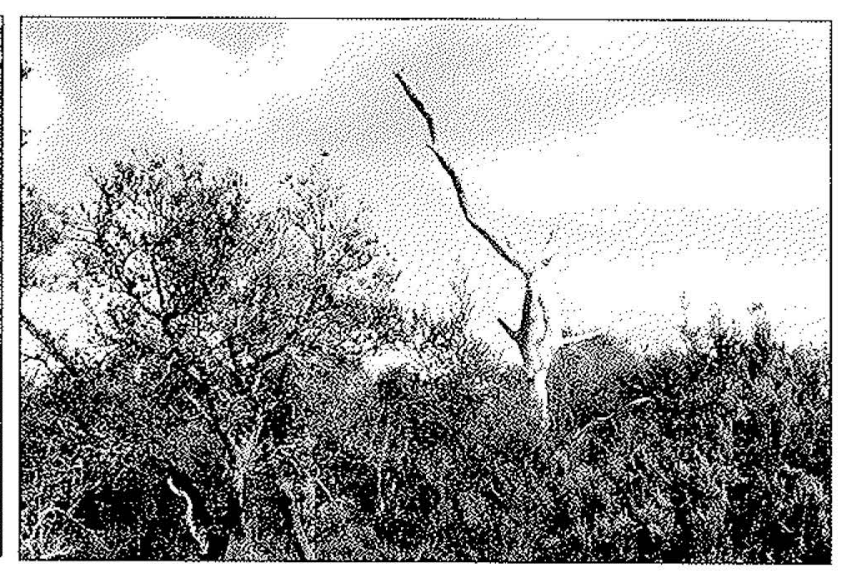

PLATE 9

Dead eucalypt at the eastem end of the back dune system.

The area of closed-forest, behind the dunes at North Bay and the $B$. marginata sand dune scrub/forest community, are important features of the back dune vegetation. $B$. marginata sand dune scrub is poorly-reserved in Tasmania (Kirkpatrick \& Harris 1995), while closed forests dominated by $N$. ligustrina occupy only a small area of Tasmania, but are widely distributed, usually confined to deep, soutl-facing rocky gullies in the driest parts of the State, where chere is topographic protection from the northwest; the direction followed by most fire fronts in Tasmania.

While the exclusion of fire is the majot management requirement for the back dune vegetation, there is also a possibility of invasion of the dunes from a population of Montpeliier Broom (Genista monspessulana (L.) L..Johnson) cutrently established behind Lagoon Bay, about $1 \mathrm{~km}$ from the eastern end of North Bay. Eradication of this stand would temove this possibility.

A major cause of loss of the back dune vegetation has been burial by sand blown from the beach in a large number of blowouts. It may be worth attempting to stabilise the blowouts at the eastern end of the beach, where the closed forest is currently being overwhelmed, although general stabilisation is probably both inappropriate and futilc. Given the low degree of anthropogenic disturbance of the dune system, the blowouts seem most likely to be attributable to 


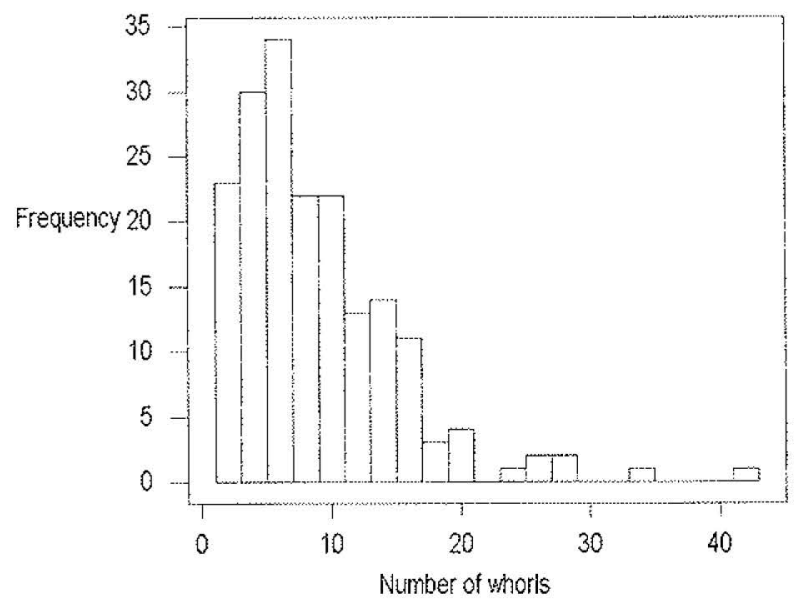

FIG. 4 - Number of whorls counted on seedlings at site 0.
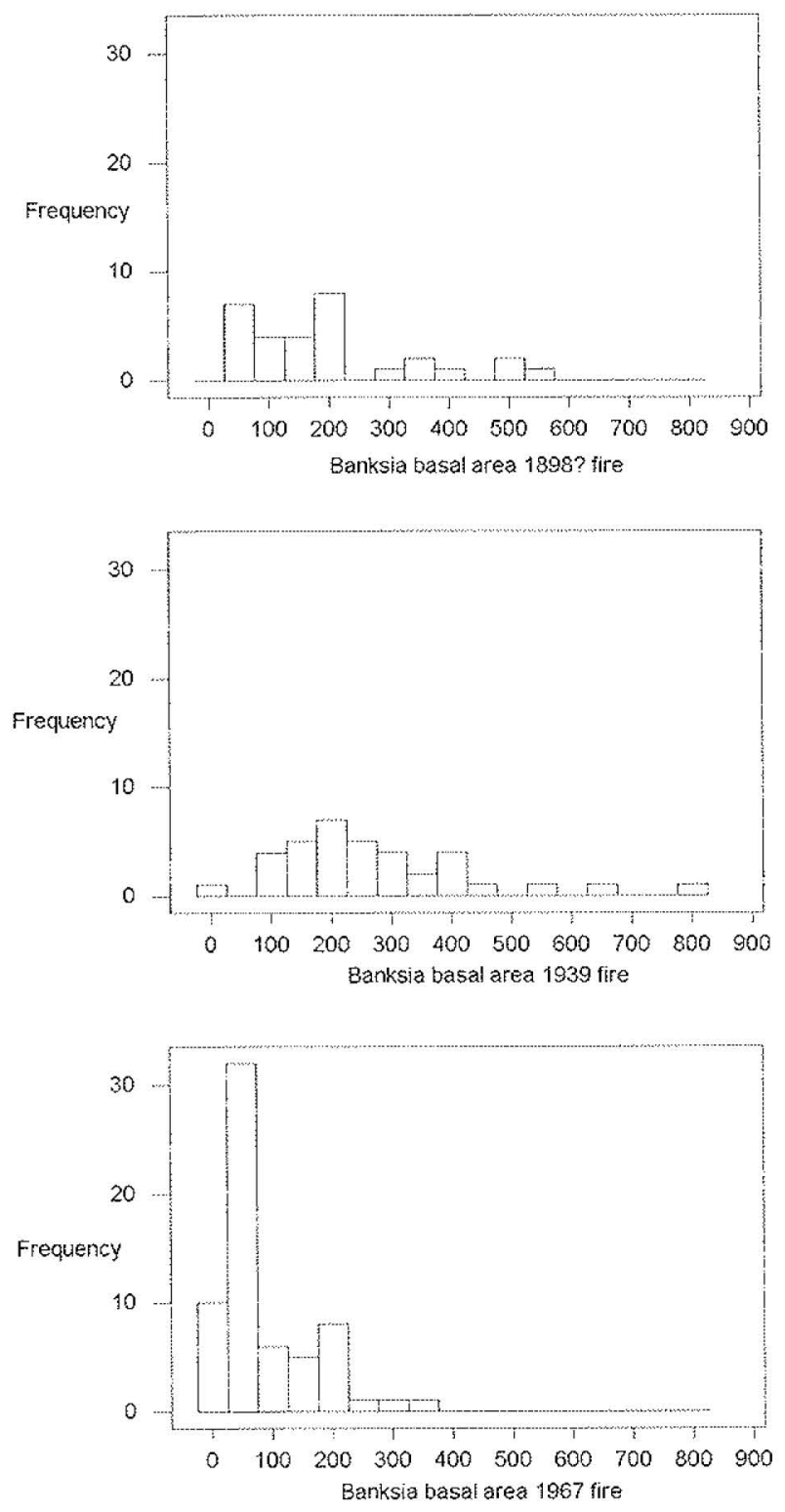

FIG. 5 - Size class distributions of bantsias at varying ages since last fire. Figures are $\mathrm{cm}^{2} / 25 \mathrm{~m}^{2}$.
TABLE 3

Means for basal area variables, ordination scores, and species richness for the four age classes of back dune vegetation.

\begin{tabular}{ccccc}
\hline \multicolumn{5}{c}{ Agc Class $^{*}$} \\
\cline { 2 - 5 } & 0 & 1 & 2 & 3 \\
\hline$n=10$ & $\mathrm{n}=10$ & $\mathrm{n}=10$ & $\mathrm{n}=15$ \\
\hline
\end{tabular}

Live basal area $\left(\mathrm{cm}^{2} / 25 \mathrm{~m}^{2}\right)$

Acacio melanoxylon

$\begin{array}{lllll}\text { Banksia marginata } & 0 & 528 & 1138 & 386\end{array}$

$\begin{array}{lllll}\text { Cassinin aculenta } & 0 & 17 & 0 & 0\end{array}$

$\begin{array}{lllll}\text { Coprosma quadrifida } & 0 & 0 & 0 & 3 / 1\end{array}$

Leptospermun lanigertm $\quad 0 \quad 06000$

$\begin{array}{lllll}\text { Leptospermum scopatitum } & 0 & 51 & 0 & 0\end{array}$

$\begin{array}{llllll}\text { Lencopogon lanceolatus } & 0 & 57 & 7 & 0\end{array}$

$\begin{array}{lllll}\text { Monotoct glaticn } & 0 & 10 & 21 & 15\end{array}$

$\begin{array}{lllll}\text { Notelaen ligustrina } & 0 & 0 & 0 & 60\end{array}$

$\begin{array}{lllll}\text { Olcaria argophylla } & 0 & 0 & 0 & 48\end{array}$

$\begin{array}{lllll}\text { Olearin linata } & 0 & 0 & 0 & 1\end{array}$

$\begin{array}{lllll}\text { Pittosponm bicolor } & 0 & 0 & 0 & 108\end{array}$

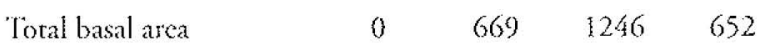

Dead basal area $\left(\mathrm{cm}^{2} / 25 \mathrm{~m}^{2}\right)$

Acacia melanoxylon

Banksia marginata

$\begin{array}{llll}0 & 0 & 19 & 0\end{array}$

Cassinia aculeata

$\begin{array}{llll}579 & 1 & 432 & 243\end{array}$

Oteatia argophylla

Leucopogon Lanceolatus

Monotoca glawen

Total basal area

0

Floristics and fichness

$\begin{array}{lllll}\text { Ordination score axis } 1 & 0.84 & 0.74 & 0.84 & 0.61\end{array}$

$\begin{array}{lllll}\text { Ordination scorc axis } 2 & 0.11 & -0.18 & -0.43 & 0.30^{* * *}\end{array}$

$\begin{array}{lllll}\text { Ordination score axis } 3 & -0.14 & 0.16 & -0.21 & 0.34^{* * *}\end{array}$

Ordination scorc axis $4 \quad-0.41 \quad 0.43 \quad 0.16 \quad-0.14 * * * x$

\begin{tabular}{lllll} 
Species richness & 10.9 & 5.7 & 8.5 & $6.4^{* *}$ \\
\hline
\end{tabular}

* 0 * youngest, $3=$ oldest.

$\mathrm{NS}=\mathrm{P}>0.05,{ }^{* *}=\mathrm{P}<0.01,{ }^{* * *}=\mathrm{P}<0.001$ 
the recent accelcrated rise in sea level (Cazenave et al. 2003), a phenomenon not controllable by local action.

\section{ACKNOWLEDGEMENTS}

We thank those members of the 2003 Vegetation Management class at the University of Tasmania who helped us collect the data used in this paper, and Tom and Cynthia Dunbabin for allowing us access to their property. The acrial photographs are used with the kind permission of the Departmens of Primary Industries, Water and Environment

\section{REFERENCES}

BOWDEN, A.R. \& KIRKPATRICK, J.R., 1974: The vegetarion of the Rheban Spit, Tasmania. Papers and Proceedings of the Royal Socicty of Tasmania 108: 199-210.

BuchaniN, A.M., 1999: A Census of the Vascular Plants of Tasmanit. Tasmanian Muscum and Art Gallery, Hobart.

CATRNAY, A., CABANIS, C., DOMINH, K., GENNERO, M.C. \& LLE PROVOST, C., 2003: Present day sea level change: observations and causes. Space Science Reviews 108: 131-144.

CHL_RDE., M. \& KIRKPBIRICK, J.B., 1989: A transect study of the sand dune vegetation of Bakers Beach, Tasmania. Papers and Procedings of the Royd Society of Tasmanin 123: $247-256$.

Ci.ARKl:, P.], 1994: Coastal dune vegetacion. In Groves, R.H. (Ed.): Anstalian Vegetation. 2nd edn. Cambridge University Press, Cambridge: 501-521.

HakrIS, S., 1991: Coastal vegetation, In Kirkpatrick, J.B. (Ed.): Tasmatidun Native Bush: a Managemen Handbook. Tasmanian Environment Centre, Hobart: 128-147.
HARRIS, S. \& KIRKPATRICK, J.B., 1996: The coastal vegetation of northeast Tasmania. Records of the Queen Victoria Muscum, Launceston 103: 121-131.

HEALY, T, 1996: Sea level rise and impacts on nearshore sedimentation: an ovefview. Geologische Rundschan 85: 546-553.

JARMAN, S.J., BROWN, M.J. \& KANTVIAS, G., 1991: Floristic and Ecologionl Studies in Fasmanian Rainforest Tasmanian NRCP Report No. 3.

KIRKPATRICK, J.B., 1993: Dry coastal ecosystems of southeastern Australia. In E. van der Maarel (Ed.): Ecosystems of the World 2B: Dry Coastal Ecosystems - Africa, America, Asia and Oceania. Elscvier, Amsterdam: 273-288.

KIRKPATRICK, J.B. \& HARRIS, S., 1995: The Conseruation of Tasmanian Dry Coastal Vasular Plant Communities. Departmene of Environment and Land Management, Hobart.

KIRKPATRICK, J.B. \& J ARRIS, S., 1999: Coastal, heath and wetland vegetation. In Reid, J.B., Hill, R.S., Brown, M.J. \& Hovendon, M. (Eds): Vegetation of Tasmania. Australiat? Biological Resources Study, Canberra: 304-332.

KOMAR, P.D., LANFREDI, N., BABA, M., DEAN, R.C., DYBR, K., HEALY, T., IBE, A.C., TERWINDT, J.H.J. \& ThOM, B.G., 1991: The response of beaches to sea-levcl changes - a review of prcdicrive modds. Journal of Coastal Research 7: $895-921$

MINCHN, R.R., 1994: DECODA: Database for Ecological Communily Data. Version 2.04. Research School of Pacific Studies, ANU, Canberra.

NICHOLLS, R.J. \& LEATHLRMAN, S.P., 1996: Adapting to scalevel rise: relative sca-level trends to 2100 for the United States. Coastal Management 24: 301 -.324.

(accepted 31 May 2004) 